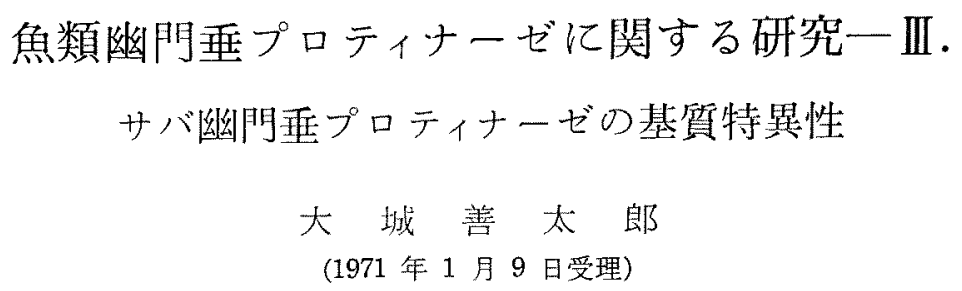

Studies on Proteinase in the Pyloric Caeca of Fishes-III.

Substrate Specificity of Mackerel Proteinase

\title{
Zentaro OOSHIRo*
}

The substrate specificity of mackerel proteinase has been investigated with the use of many synthetic substrates.

Mackerel proteinase hydrolysed the following substrates: $\mathrm{N} \alpha$-benzoyl-L-arginineamide, chloroacetyl-L-leucine, acetyl-DL-methionine and chloroacetyl-DL-methionine, while it did not hydrolyse the following substrates: carbobenzoxy-L-glutamyl-Ltyrosine, acetyl-L-tyrosineamide, $\mathrm{N} \alpha$-benzoyl-L-tyrosineamide and $\varepsilon$-benzoyl- $\alpha$-acetylDL-lysine. These results show that the proteinase has very broad specificity.

Effects of various metals on the activity of this enzyme were examined. No effect was brought forth by di-valent metal ions.

Experiments with $\mathrm{N}$-acylated derivatives of amino acid, such as methionine and leucine, indicated that the proteinase has an optical specificity, i.e. it hydrolyses the $\mathrm{L}$-isomer, but not the $\mathrm{D}$-isomer. It may be of interest that this enzyme can be used for the optical resolution of acylated DL-amino acids.

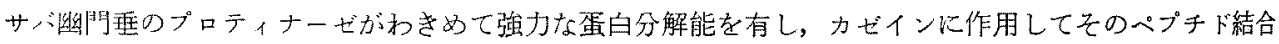
の70\%を開裂させることは，前報 ${ }^{1}$ で述へたたこの事赛は，サバ幽門垂プロティナ一ゼの基質特異性が非

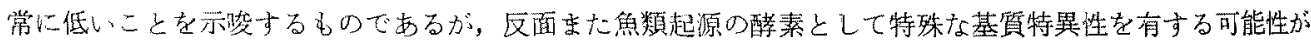
あり，比䡆醉素学的にも興味のある問題であると思われる。本報告で，各種の合成基質を用いてサバ幽門

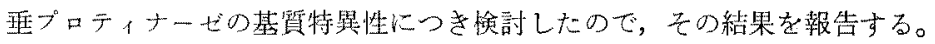

\section{実 験 方 法}

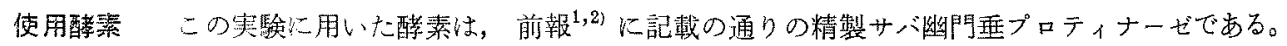
このものは夕ロマトグラフ的に単一で，分子量的にも均一，乙かも電気泳動的にる単一なるのである。

基質使用した合成基質は Table 1 亿示す通りであり，阪大理学部ならびに同蛋白質研究所蛋白質研究

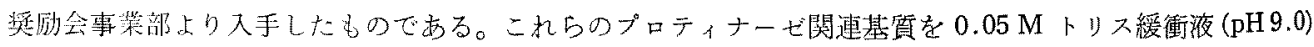

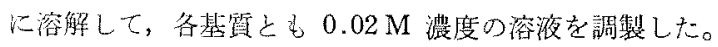

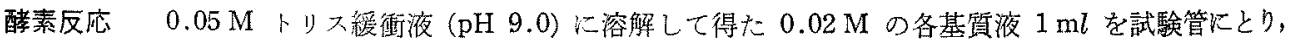
これを $37^{\circ} \mathrm{C}$ に約 3 分間于温，これに別心予温しておいた酵絜溶液 $(0.028 \mathrm{mg}-\mathrm{N} / \mathrm{ml}) 1 \mathrm{ml}$ を加えて所定時 間反応させ， $0.4 \mathrm{M}$ トリクロル酢酸 (TCA) 溶液 $1 \mathrm{~m} l$ を加えて酵素反応を停止させた。反応時間は 10 分

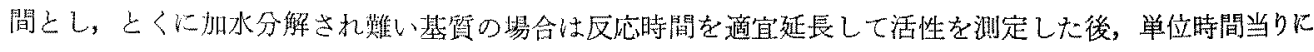

* 鹿睍鼻大学水産学部 (Faculty of Fisheries, Kagoshima Univ., Shimoaratacho, Kagoshima). 
Table 1. The action of mackerel proteinase on various types of substrates $\left(37^{\circ} \mathrm{C}\right)$.

\begin{tabular}{l|c}
\hline \multicolumn{1}{c|}{ Substrate } & Relative rate \\
\hline N $\alpha$-Benzoyl-L-arginineamide & 100 \\
N $\alpha$-Benzoyl-L-tyrosineamide & 3 \\
N $\alpha$-Acetyl-L-tyrosineamide & 1 \\
Carbobenzoxy-L-glutamyl-L-tyrosine & 3 \\
Carbobenzoxy-glycyl-L-phenylalanine & 7 \\
Chloroacetyl-L-leucine & 132 \\
Chloroacetyl-DL-leucine & 130 \\
N-Acetyl-DL-methionine & 60 \\
Chloroacetyl-DL-methionine & 98 \\
N-Acetyl-DL-tryptophan & 10 \\
$\varepsilon$-Benzoyl- $\alpha$-acetyl-DL-lysine & 0
\end{tabular}

The relative rates were compared with the standardvalue of 100 for $\mathrm{N} \alpha$-benzoyl-L-arginineamide.
換算して表示した。

酵素活性は酵素反応により，基筫上 してアミノ酸のアシル誘導体を使用し た場合には遊離生成した $\alpha-$ ア ミ基, アミノ酸アミドの場合に怯遊離生成し たアンモニアをそれぞれニンとドりン 発色法 ${ }^{3,4}$ に上り比色定量した。発色 值はすべてロイシン当量として算出し て表示した。

各基質に対する加水分解度は便宜上 $\mathrm{N} \alpha$-benzoyl-L-arginineamide の場合 を100としたときの相対值で比校した。

\section{実験結果および考察}

基質特異性について 各種の合成 基質に対するサバ幽門垂プロティナー

ゼの活性を測定した結果をTable 1 に記載する。

Table 1 から見取机るよらに，本酵素は N $\alpha$-benzoyl-L-arginineamide 沉作用して，そのフマイド結合 を水解開裂する活性が強いことが明らかとなつた。N $\alpha$-benzoyl-L-arginineamide はトリプシンの典型的な

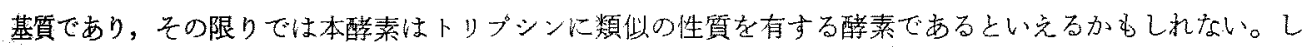
かしながら，すでに前報りにおいて明らかにしたよらに，カゼインに対する作用が本醉素とトリプシンでは著

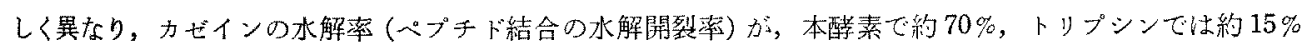
相当であることから，両者恃明らか汇異なるものであると思われる。プロティナーゼの基質特異性を論ずる 場合沈，合成ペプチト類とカぜインのような蛋白質に対する作用様式から総合的に判断することが必要で あるといらことが痛感される。

さらにまた，本酵素は chloroacetyl-L-leucineに対しても顕著な活性を示した。chloroacetyl-L-leucine をよく水解する醉素として知られているものに，exopeptidase であるカルボキシペプチダーゼがある。す て炕著者はサ，幽門垂からカルボキシペプチダーゼをを分離精製して，その性質を明らかにしているが，本 精彆プロティナーゼ区分にカルボキシペプチダーゼが混在する疑点が皆無とは言い切れない。しかしながら 本䤃素がカルボキシペブチダーゼの典型的な基質である carbobenzoxy-glycyl-L-phenylalanine に対して

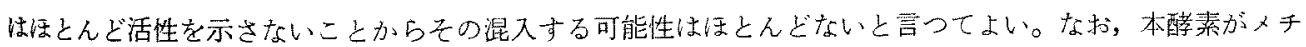
オンンの N-アシル誘導体に対して著しい活性を示すことも特幑的である。この場合, アシル基の種類に よつて乐解作用に影響が見られ, electronegative な chloroacetyl-DL-methionine の方が acetyl-DLmethionine より 2 倍の速さで加水分解されることも併せて認わられた。

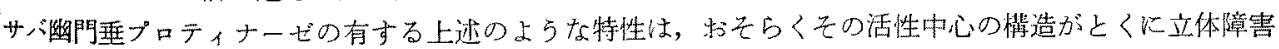
の少ないような原子配列，すなわち立体構造を有するために，多様な棈造の基質に親和性を示すのではない かとも考えられる。これらの点の解明は醉素作用の本質に関連するるのとして興味深い研究課題と思われる。

光学特異性について 前述の通り, サ、幽門垂プロティナーゼが, L-ロイシン, DLーロイシンおよび DLメチオニンのアシル誘導体をよく水解することが明らかとなつたが，あらためて chloroacetyl-L-leucine, chloroacetyl-DL-leucine, chloroacetyl-DL-methionine 拉よび N-acetyl-DL-methionine に対する本酵素 の作用様式を検討した。すなわち $0.05 \mathrm{M}$ ベロナール緩衝液（pH 8.0）にとかした $0.02 \mathrm{M} \mathrm{N}$ ーフシルロイ

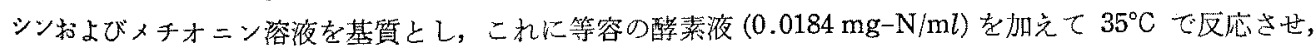
醋素反応により水解遊離したアミノ酸をニンヒドリン呈色法により定量して, その加水分解度を求めた。そ 


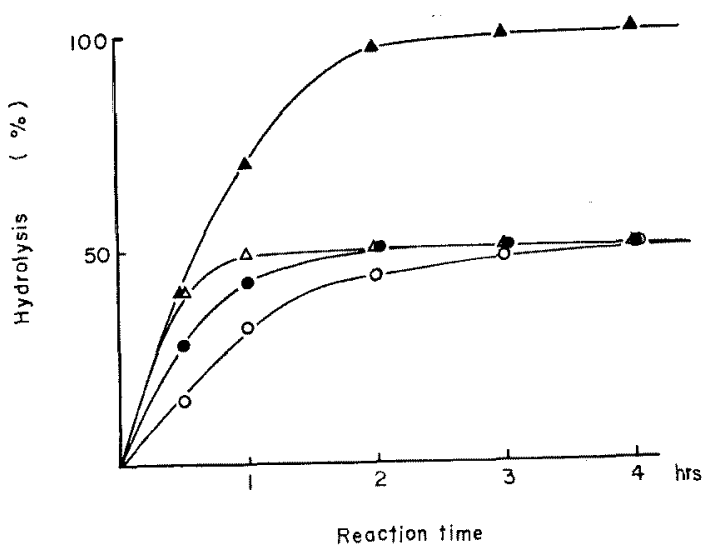

Fig. 1. Asymmetric hydrolysis of $\mathrm{N}$-acylated amino acid by mackerel proteinase.

The reaction mixtures were composed of equal volume of $0.02 \mathrm{M} \mathrm{N}$-acylated methionine and leucine in $0.05 \mathrm{M}$ veronal buffer and enzyme solution $(0.0184 \mathrm{mg}-\mathrm{N} / \mathrm{ml})$.

The reaction was made at $\mathrm{pH} 8.0,35^{\circ} \mathrm{C}$.

-- Chloroacetyl-DL-methionine.

O-O: N-Acetyl-DL-methionine.

$\triangle-\triangle:$ Chloroacetyl-DL-leucine.

$\Delta-\Delta$ : Chloroacetyl-L-leucine.

Table 2. The effect of divalent metal ions on the activity of mackerel proteinase.

\begin{tabular}{c|c}
\hline Metal ions & Relative activity $(\%)$ \\
\hline Control (without metal ion) & 100 \\
Ca++ & 98.1 \\
$\mathrm{Mg}^{++}$ & 94.2 \\
$\mathrm{Mn}^{++}$ & 99.2 \\
$\mathrm{Zn}^{++}$ & 108.2 \\
$\mathrm{Co}^{++}$ & 110.3
\end{tabular}

The enzyme activity of mackerel proteinase was noted after it was pre-incubated with $0.01 \mathrm{M}$ various metal ions for 30 minutes at $37^{\circ} \mathrm{C}$.

The final concentration of metal ions in each enzyme-substrate reaction mixture was $0.002 \mathrm{M}$.
れらの結果を Fig. 1 に示した。图で明ら かな上らに, DLーアミノ酸のNーアシル誘導 体红対しては $50 \%$ 相当が不斉水解される ことが認められた。しかし chloroacetylL-leucine に対してはこれをほとんど完全 に加水分解して L-ロイシンを遊離するこ とが明らかとなつだ。以上の通り本酵素は 合成ラセミアミノ酸のらち，DLーロイシン 扣よび $\mathrm{DL}$ メチオンなどの $\mathrm{N}$ ーアシルア ミ八酸を不斉水解しらることから L->ミ 八酸の収得に活用しらるむの之思われる。

\section{酵素活性に及ばす金属イオンの影響}

金属イオン特以 $\mathrm{Mn}^{++}, \mathrm{Mg}^{++}, \mathrm{Ca}^{++}, \mathrm{Zn}^{++}$, $\mathrm{Co}^{++}$など 2 洒金属イオンによつて多くの exopeptidase が活性化 ${ }^{6 \sim 9)}$ さることはす でによく知られているところであるが， endopeptidase である proteinase が金属 イオンによつて賦活される例 ${ }^{10}$ 12) りないよらである。 サバ幽門垂プロティナーゼに $\mathrm{Ca}^{++}$, $\mathrm{Mg}^{++}, \mathrm{Mn}^{++}, \mathrm{Zn}^{++}$括よび $\mathrm{Co}^{++}$(いずれ も塩化物を用いた）を加㫕て preincubate した後基質を加えて反応させ，酵素活性に お上济すこれら金属イオンの影響を調べた。 その結果は Table 2 に示す通りである。 表から明らかな上らに，いずれの金風イ オンも酵菜活性に対しほとんぞ影響を示さ なかつたが， $\mathrm{Zn}^{++}, \mathrm{Co}^{++}$によつてわずか に活性増加が認められた。

要約

サ：汹門垂から分離精製されたブロティ ナーゼの基質特異性ならびに光学特異性索 明らかにするための検討を行ない，次の結 果索得た。

1.サバ幽閒垂プロティナーゼを諸種の 合成基斦に作用させてその基質特異性を調べた。その結果きわ始い基質特異性を有することが推定され t:。

2. このブロティナーセとよつて，よく加水分解される基質としては， N $\alpha$-benzoyl-L-arginineamide， chloroacetyl-L-leucine, chloroacetyl-DL-leucine, chloroacetyl-DL-methionine 拧よび acetyl-DLmethionine などであることが明らかにされた。

3. 本酵䋕が合成 $(\mathrm{DL})$ アミノ酸のうち，とくにロイシン，メチオニンのアシル誘導体に作用して，これ らを不斉水解することが認められた。このことは，本醅秦がこれらのアミ，酸の光学分割に利用できる可能 
性を示するのである。

4、酵素活性におよぼす種々の 2 洒金属イオンの影響につき検討したが，ほとんど影響を示さなかつた。

文献

1) 大城善太郎：本誌, 37, 145 148 (1971).

2) 大城普太郎: 本誌, 34, 847 852 (1968).

3) E. W. YEMM and E. C. CoCKING: Analyst, 80, 209 213 (1955).

4) S. Moore and W. H. Stein: J. Biol. Chem., 211, $907 \sim 913$ (1954).

5) 大城善太郎：鹿大水紀要, 11, $111 \sim 151$ (1962).

6) E. L. SмIтн: Federation proc., 8, $581 \sim 588$ (1949).

7) E. L. Smith: J. Biol. Chem., 176, 21 32 (1948).

8) E. L. Sмітн: Advances in Enzymol., 12, $191 \sim 257$ (1951).

9) E. L. Smith and D. H. SpackmanN: J. Biol. Chem., 212, $271 \sim 299$ (1955).

10) L. Gorini: Biochim. Biophys. Acta, 6, $237 \sim 255$ (1951).

11) K. Morihara: Bull. Agr. Chem. Soc. Japan, 23, 49 59, $60 \sim 63$ (1959).

12）森原和之・增尾栄太郎：醉素化学シンポジウム，14，281 286 (1960). 